refuse this we give $2 \mathrm{mg}$ phytomenadione (vitamin $\mathrm{K}_{1}$ ) orally at birth and at 12 and 24 hours of age. We await information on the efficacy of this oral regimen. Recent work by Cornelissen et al will further fuel the controversy as they suggest that a single dose of vitamin $\mathrm{K}$, whether given orally or intramuscularly, is insufficient to protect against late haemorrhagic disease of the newborn." I wonder whether, in the meantime, the adverse publicity surrounding vitamin $\mathrm{K}$ will result in a resurgence of this preventable condition; I hope that it remains a condition that is rarely seen.

A W R KELSALI

Neonatal Intensive Care Unit,

Rosie Maternity Hospita

Cambridge $\mathrm{CB} 12 \mathrm{QQ}$

1 McNinch AW, Upton C, Samuels M, Shearer MJ. Plasma concentrations after oral or intramuscular vitamin $\mathrm{Kl}$ in ild 1985;60:814-8.

2 McNinch AW, Tripp JH. Haemorrhagic disease of the newborn in the British Isles: two year prospective study. BMf 1991;303 $1105-9$

3 Golding J, Greenwood R, Birmingham K, Mott M. Childhood cancer, intramuscular vitamin $\mathrm{K}$, and pethidine given during labour. BMF 1992;305:341-6. (8 August.)

+ Lawrence Beech BA. Intramuscular vitamin K and childhord cancer. BMF 1992;305:710. (19 September.

5 Dunn HP. Intramuscular vitamin $K$ and childhood cancer. BM. 1992;305:710. (19 September.)

6 Cornelissen EAM, Kollee LAA, De Abreu RA, van Baal JM. Effects of oral and intramuscular vitamin $\mathrm{K}$ prophylaxis on vitamin $\mathrm{Kl}$, PIVKA-II, and clotting factors in breast fed infants. Arch Dis Child 1992;67:1250-4.

\section{Antenatal screening for Down's syndrome}

EDITOR,-In maternal serum screening for Down's syndrome based on several markers the human chorionic gonadotrophin assay can measure either the intact molecule or the free $\beta$ subunit (a small fraction of the total), or both. Kevin Spencer advocates using an assay of the free $\beta$ subunit, and, though $\mathrm{N} J$ Wald and colleagues are uncertain, ${ }^{2}$ we believe that there are two good reasons to prefer the free $\beta$ subunit.

Firstly, when screening takes place-generally at 15-20 weeks' gestation - the predicted detection rate is higher for the free $\beta$ subunit. In metaanalysis of 17 studies that used intact or total human chorionic gonadotrophin the average level for 530 Down's syndrome pregnancies was $2 \cdot 0$ multiples of the normal gestation specific median (95\% confidence interval $1 \cdot 9$ to $2 \cdot 1$ ). ${ }^{3}$ When this approach is applied to the five reported studies that used free $\beta$ (the four cited by Spencer ${ }^{2}$ and that of Ryall et $a l^{4}$ ) the average level for 228 affected pregnancies is $2 \cdot 3$ multiples of the median $(2 \cdot 1$ to $2 \cdot 5)$.

The table shows the predicted effect of the

Detection rate and false positive rate (percentages) obtained in screening for Down's syndrome pregnancies with maternal serum a fetoprotein, unconjugated oestriol, and human chorionic gonadotrophin (free $\beta$, intact or total) concentrations ${ }^{\star}$

\begin{tabular}{lccccc}
\hline & \multicolumn{3}{c}{ Human chorionic gonadotrophin } \\
\cline { 2 - 3 } & \multicolumn{2}{c}{ Free $\beta$} & & \multicolumn{2}{c}{ Intact or total } \\
\cline { 2 - 3 } \cline { 5 - 6 } $\begin{array}{l}\text { Cut off } \\
\text { riskt }\end{array}$ & $\begin{array}{c}\text { Detection } \\
\text { rate }\end{array}$ & $\begin{array}{c}\text { False } \\
\text { positive } \\
\text { rate }\end{array}$ & & $\begin{array}{c}\text { Detection } \\
\text { rate }\end{array}$ & $\begin{array}{c}\text { False } \\
\text { positive } \\
\text { rate }\end{array}$ \\
\hline 1 in 150 & 61 & 2.9 & & 49 & $2 \cdot 4$ \\
1 in 200 & 66 & $4 \cdot 0$ & & 54 & 3.3 \\
1 in 250 & 69 & $5 \cdot 0$ & & 58 & $4 \cdot 4$ \\
1 in 300 & 72 & $5 \cdot 9$ & & 60 & $5 \cdot 4$ \\
1 in 350 & 74 & $6 \cdot 8$ & & 63 & $6 \cdot 4$
\end{tabular}

^ Rates predicted from multivariate gaussian model with medians, standard deviations, and correlation coefficients of Spencer et al $l^{\varsigma}$ and maternal age distribution of England and Wales in 1989 and 1990.

$\dagger$ Result of screening is positive if risk of Down's syndrome term pregnancy exceeds cut off. increase in levels when screening using human chorionic gonadotrophin in combination with $\alpha$ fetoprotein and unconjugated oestriol. For the tabulated cut offs the predicted detection rate is 11 $12 \%$ higher for free $\beta$, with a $0 \cdot 4-0 \cdot 7 \%$ increase in the false positive rate. For a fixed false positive rate there is an $8-10 \%$ higher predicted detection rate for free $\beta$. Possibly some of the increase in levels is an artefact of storage of the serum samples. This, however, is likely to be a small effect since the results of prospective screening at Oldchurch Hospital' are consistent with the model predictions: the detection rate is $73 \%(11 / 15)$ for a false positive rate of $5 \cdot 5 \%$

The second reason for preferring the free $\beta$ subunit is that, like $\alpha$ fetoprotein and unconjugated oestriol but unlike intact human chorionic gonadotrophin, it can be used for screening before 15 weeks. In the six published studies (three cited by Wald and colleagues ${ }^{2}$ and three others $\left.{ }^{6 . x}\right)$ of samples obtained in early pregnancy tested using intact or total human chorionic gonadotrophin the average level from 102 Down's syndrome pregnancies was only 1.2 multiples of the normal median. In contrast, in a recent study that used a free $\beta$ assay at 7-13 weeks to test 13 affected pregnancies the average level was 1.85 multiples of the median, which is consistent with the average level after 15 weeks' gestation.

These reasons have compelled us to change to assaying the free $\beta$ subunit in our screening programme for Down's syndrome and to offer screening from 13 weeks' gestation. A disadvantage of screening for the syndrome before 15 weeks is that the $\alpha$ fetoprotein concentration cannot be interpreted in relation to neural tube defects. Many centres, however, would be confident enough in their use of routine ultrasound examination in screening for anomalies to abandon biochemical screening for this disorder in order to provide an earlier diagnosis of Down's syndrome.

H CUCKLE R LILFORD

Institute of Epidemiology and

Health Services Research,

University of Leds,

Leeds LS2 9LN

1 Spencer K. Antenatal screening for Down's syndrome. BMf 1992;305:769. (26 September.)

2 Wald NJ, Kennard A, Densem JW, Chard T, Butler L. Antenatal screening for Down's syndrome. BMF 1992;305:771 (26 September.)

3 Wald N, Cuckle H. Biochemical screening. In: Brock DJH, Rodeck C, eds. Prenatal diagnosis and screening. Edinburgh: Churchill Livingstone, 1992.

+ Ryali RG, Staples AJ, Robertson EF, Pollard AC. Improved performance in a prenatal screening programme for Down's syndrome incorporating serum-free hCG subunit analyses. Prenat Diagn 1992;12:251-61.

5 Spencer K, Coombes EJ, Mallard AS, Milford Ward A. Free beta human choriogonadotropin in Down's syndrome screening: a multicentre study of its role compared with other biochemical markers. Ann Clin Biochem 1992;29:506-18.

6 Johnson A, Cowchock FS, Darby M, Wapner R, Jackson LG. First trimester maternal serum alpha-fetoprotein and chorionic gonadotrophin in ancuploid pregnancies. Prenat Diagn 1991; 11:443-50.

7 Van Lith JMM. First-trimester maternal serum human chorionic gonadotrophin as a marker for fetal chromosomal disorders. Prenat Diagn 1992; 12:495-504.

8 Kratzer PG, Golbus MS, Monroe SE, Finkelstein DE, Taylor RN. First-trimester aneuploidy screening using serum human chorionic gonadotropin (hCG), free $\alpha \mathrm{hCG}$, and progesterone. Prenat Diagn 1991;11:751-65.

9 Spencer K, Macri JN, Aitken DA, Connor JM. Free $\beta$-hCG as first-trimester marker for fetal trisomy. Lancet 1992;339:1480.

EDITOR,-Antenatal screening for Down's syndrome using maternal serum markers during the second trimster together with the woman's age is currently under investigation.' Haddow et al have reported the result of a large prospective study. ${ }^{2}$ They showed the validity of predictions based on retrospective studies, indicating that use of the three markers $\alpha$ fetoprotein, chorionic gonadotrophin, and unconjugated oestriol is more effective than use of maternal serum $\alpha$ fetoprotein alone. Their results also suggested that not using unconjugated oestriol values would lead to a $5 \%$ reduction in the rate of detection.

We conducted a prospective study using the two markers human chorionic gonadotrophin and unconjugated oestriol together with the woman's age. Such a protocol has been recommended for prenatal screening centres that do not measure $\alpha$ fetoprotein routinely to detect neural tube defects and are willing to use only two markers instead of three. We studied 26128 women aged 18 to 37 who underwent prenatal screening for Down's syndrome between January 1990 and April 1992 in a limited area in north west France where the annual number of births is around 20000 . Gestational age was estimated by biparietal diameter ultrasonography before screening. Predictive risk factors were calculated by crossing hormone measurements with maternal age. Eligibility for amniocentesis or chorionic villus sampling was set up at a risk cut off of 1 in 150 , leading to a positive screening rate of $4 \cdot 7 \%$. The risk factor calculation was based on published retrospective studies. ${ }^{+5}$ Recent readjustment of reference values from our own study, however, indicated that risk factors had been overestimated and that our risk cut off was nearer 1 in 200 .

Results of prospective study of prenatal screening for Down's syndrome based on human chorionic gonadotrophin and unconjugated oestriol concentrations and woman's age, according to second trimster risk cut off of 1 in 200

\begin{tabular}{|c|c|c|c|c|c|}
\hline \multirow[b]{2}{*}{$\begin{array}{c}\text { Maternal } \\
\text { age } \\
\text { (years) }\end{array}$} & \multirow[b]{2}{*}{$\begin{array}{c}\text { No } \\
\text { screened }\end{array}$} & \multirow[b]{2}{*}{$\begin{array}{c}\text { Positive } \\
\text { screening } \\
(\%)\end{array}$} & \multicolumn{2}{|c|}{$\begin{array}{c}\text { Cases of } \\
\text { Down's syndrome }\end{array}$} & \multirow[b]{2}{*}{$\begin{array}{l}\text {-Detection } \\
\text { rate } \\
(\%)\end{array}$} \\
\hline & & & Detected & $\begin{array}{c}\text { Not } \\
\text { detected }\end{array}$ & \\
\hline $18-29$ & 18382 & $3 \cdot 6$ & 6 & 6 & 50 \\
\hline $30-37$ & 7746 & $7 \cdot 4$ & 13 & 5 & 72 \\
\hline All ages & 26128 & $4 \cdot 7$ & 19 & 11 & 63 \\
\hline
\end{tabular}

The table shows the effectiveness of our protocol. As expected, the detection rate was higher in the group of older women. We also observed that not using unconjugated oestriol values would lead to a net loss in detection of three cases (four cases missed and one additional case detected) for a similar positive screening rate $(4 \cdot 6 \%)$. Taken together with the data from Haddow et al, our results confirm the usefulness of measuring unconjugated oestriol concentrations - this had been questioned in a study by Macri et al. ${ }^{\circ}$

NATHALIE LEPORRIER MICHEL HERROU PIERRE LEYMARIE

Centre Hospitalier et Universitaire de Caen,

14033 Caen cedex,

France

I Correspondence. Antenatal screening for Down's syndrome. BM7 1992;305:768-71. (26 September.)

2 Haddow JE, Palomaki GE, Knight GJ, Williams J, Pulkkinen A, Canick JA. Prenatal screening for Down's syndrome with use of maternal serum markers. $N$ Engl f Med 1992;327:588-93.

3 Cuckle HS, Wald NJ. Screening for Down's syndrome. In: Lilford R, ed. Prenatal diagnosis and prognosis. London: Butterworth, 1990:67-91

4 Wald NJ, Cuckle HS, Densem JW, Nanchahal K, Canick $\mathrm{JA}$, Hadow JE, et al. Maternal serum unconjugated oestriol as an antental screening test for Down's syndrome. Br J Obstet Gynaecol 1988;95:334-41.

5 Muller F, Boué A. A single chorionic gonadotropin assay for maternal serum screening for Down's syndrome. Clin Genet 1990;10:389-98.

6 Macri J, Kasturi R, Krantz D, Cook EJ, Sunderii SG, Larsen JW. Maternal serum Down syndrome screening: unconjugated estriol is not useful. Am J Obstet Gynecol 1990;162:672-3.

EDITOR, - In our recent letter on antenatal screening for Down's syndrome we said that the effect of the age distribution of women on the performance of serum screening for Down's syndrome would be small and that, regardless of the variation in the age distribution, such screening would yield a higher 